\title{
AN ANALYSIS OF THE FACTORS IN PREFERENCES OF STUDENTS FOR VOLLEYBALL ON CAMPUS AND FAMILY AND SOCIETY FACTORS ${ }^{1}$
}

\section{KAMPÜSTE VOLEYBOL SPORUNU TERCİH EDEN ÖĞRENCILERIN BU TERCIHLERINDEKİ ETKENLER ILE AIILE VE TOPLUM FAKTÖRLERININ INCELENMESI}

\author{
Mustafa KARADA $\breve{G}^{1}$, Yüksel SAVUCU ${ }^{2}$, Yonca Süreyya BIÇER ${ }^{3}$, Ali Serdar YÜCEL ${ }^{4}$, \\ Ercan GÜR ${ }^{5}$, Serdar ORHAN \\ ${ }^{1-6}$ Firat University Faculty of Sports Sciences Elazig / Turkey
}

ORCID ID: 0000-0002-0299-4198 $, 0000-0002-2749-6806^{2}, 0000-0003-3072-8302^{3}, 0000-0002-4543-4123^{4}$, 0000-0001-6690-828X, $0000-0002-7988-5045^{6}$

Öz: Amaç: Bu araştırmada, Fırat Üniversitesi kampüsünde voleybol sporunu tercih eden öğrencilerin bu seçimlerindeki etkenler ile aile ve toplum faktörlerinin etkisini belirlemek amaçlanmıştır. Yöntem: Araştırma grubunu Fırat Üniversitesi kampüsünde voleybol sporunu tercih eden, bayan-erkek ögrenciler oluşturmaktadır. Araştırmada tarama (survey) modeli kullanılarak veri toplama amaciyla anket uygulanmıştır. 23 sorudan oluşan ankette toplam 97 birey anketi değerlendirilmeye alınmıştır. İstatistiki çözümler için SPSS 21.0 paket programından yararlanılmıştır. İstatistiksel işlem olarak ki-kare, frekans ve yüzde testleri uygulanmıştır. Anlamlılık değeri p $<0.05$ olarak alınmıştır. Bulgular: Ailelerin çocuklarının spor yapmalarına her zaman olumlu yaklaştıkları görülmüş (\%66), ve cinsiyet arasında anlamlı bir farklılığa rastlanmamıştır. Öğretmenlerin bireylerin voleybol branşını seçmelerinde daha etkili olduğu $(\% 54,6)$, bunun yanı sıra arkadaşlarının etkisinin ise $\% 29,0$ olduğu görülmüştür $(\mathrm{p}<0,05 ; 002)$. Ayrıca cinsiyet arasında anlamlı bir farklılığa da rastlanmamıştır. Sonuç: Yapılan çalı̧̧mada özellikle öğretmenlerin öğrencilerin voleybol sporunu yapmalarında olumlu etki sağladığı görülmüştür. Kampüste spor malzeme ve tesis yetersizliğinin bireyleri olumsuz yönde etkilediği düşünülmektedir.

Anahtar Kelimeler: Öğrenci, Voleybol, Toplum, Aile
Abstract: Objective: The purpose of this study is to determine the effect of family and society factors on individuals preferring and doing volleyball on campus of Firat University. Method: The study groups are composed of female and male students in Firat University who prefer volleyball. Survey model has been used in the research and the questionnaire has been applied for the purpose of data collection. The questionnaire composed of 23 items has been evaluated and a total of 97 individuals have participated in the study. SPSS 21.0 software package has been utilized for statistical solutions. Chi-square, frequency and percentage tests have been applied. Significance has also been obtained as $p<0.05$. Results: It has been observed that families positively approach to their children's doing sports $(66 \%)$ and no significant difference has been observed between sexes. It has also been determined that teachers are more effective in preference of individuals for volleyball $(54.6 \%)$ and the effect of friends is $29.0 \%$ $(\mathrm{p}<0.05 ; 002)$. No significant difference has been observed between sexes. Conclusion: It has been established that especially teachers provide positive effect to students in playing volleyball. It is thought that the inadequacy of sports materials and facility on campus negatively affect individuals.

Key Words: Student, Volleyball, Society, Family

Doi: $10.17363 / S S T B .2017 .4 .4$

(1) Corresponding Author: A. Serdar YÜCEL, Firat University, Faculty of Sports Sciences, Elazig / Turkey, alsetu_23@ hotmail.com, Received: 23.07.2017, Accepted: 08.12.2017, Type ofarticle (Research-Application) Conflict of Interest: None / "None of Ethics Committee" 


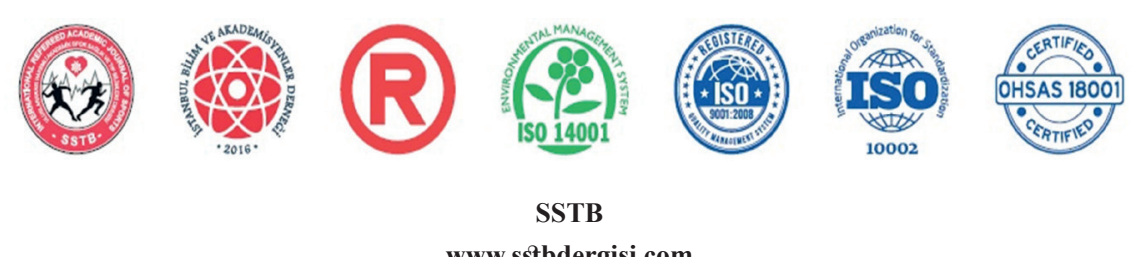

www.sstbdergisi.com

International Refereed Academic Journal of Sports, Health and Medical Sciences

October - November - December Issue 25 Autumn Winter Season Year: 2017

JEL CODE: A220-M490 ID:354 K:129

ISSN Print: 2146-8508 Online 2147-1711

(ISO 18001-OH-0090-13001706 / ISO 14001-EM-0090-13001706 / ISO 9001-QM-0090-13001706 / ISO 10002-CM-0090-13001706)

(TRADEMARK)

(2015/04315- 2015-GE-18972)

\section{INTRODUCTION}

The importance of physical education and sports is huge for individuals to establish good relations with each other and within society. Sports is a process with physiological, psychological, social and sensitive effects (Kanat vd., 2013: 461; Kırımoğlu vd., 2010: 101-108). Physical education is a general concept that includes all educational physical activities such as play, gymnastics and sports and is training carried out within and through the physical activities (Larson, 1970). Sports, which is an integral part of physical education, is presented as a competitive, solidaristic and cultural concept that allows socialization, improves spiritual and physical skills and is performed as a profession individually or in a group, with or without tools under certain rules in a way to occupy leisure or all time (Özmen, 1999: 1-208; cited from Erkal, 1998: Cengiz and Taşmektepligil, 2016: 220-240). In another definition, sport can be defined as activities requiring physical and mental activity and based on competition and contest that individuals or groups do for health, entertainment, show or adventure where individuals' cognitive, emotional and psychomotor features are planned and programmed in accordance with certain rules (Sunay, 2010: 1-162; Özbayraktar vd., 2008). Physical education and sports being an important part of human life enable a person to have a balanced per- sonality by strengthening both the soul and the body structure and health (Sunay, 2010).

Thinking sports together with physical education concept is the right approach while relating sports with the education. Physical education and sports are mutually complementary facts within the modern sense of education (Özbayraktar vd., 2008). Physical education and sports are the most effective education and health activity that is directly related to human health, character development, morale and efficiency in individualistic terms and to the potential and existence of manpower with strong, stable and common feelings and behaviors in national terms (Yetim, 2005).

The first place where individuals see the world of physical education and sports is family. This effect of family on socialization determines whether children will participate in physical education and sports activities and in what way they will if they participate. The approach of families in this matter is nearly the most determinant factor concerning whether children will participate in these activities (DPT, 1983).

The fact that parents are involved in sports has a positive effect on the child's participation in the sport, even in the majority of the sports community (Erdemli, 1991; Öztürk, 1998). Positive appraisal of sports by parents increases the interest in sports between gen- 


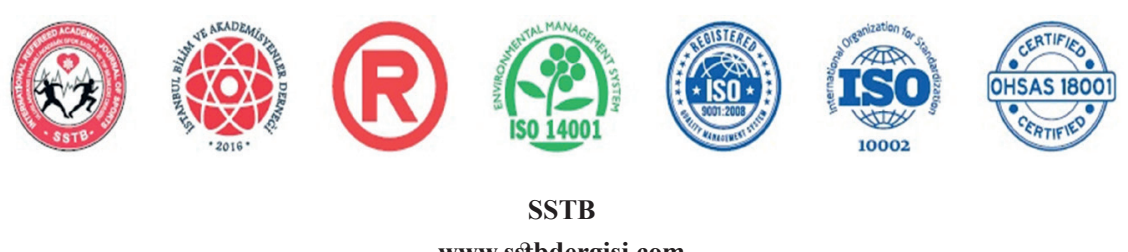

Www.sstbdergisi.com

International Refereed Academic Journal of Sports, Health and Medical Sciences

October - November - December Issue 25 Autumn Winter Season Year: 2017

JEL CODE: A220-M490 ID:354 K:129

ISSN Print: 2146-8508 Online 2147-1711

(ISO 18001-OH-0090-13001706 / ISO 14001-EM-0090-13001706 / ISO 9001-QM-0090-13001706 / ISO 10002-CM-0090-13001706) (TRADEMARK)

(2015/04315- 2015-GE-18972)

erations. In addition, children may be interested and participate in sports more if families continue doing sports or watch sports programs on TV regularly, if families encourage their children for the active participation in sports and sports is a general subject in the family (DPT, 1983; Öztürk, 1998). Sports are of great importance in directing children to sports activities as of primary school and having them adopt a good habit. The subject of the sports has also been addressed by the world countries. The US encouraged successful students for sports by awarding scholarships and prizes while the physical education courses at schools were increased with a law in France (Mcpherson et al., 1986).

In these definitions, physical education and sports have many benefits for the individuals. Physical education and sports have significant effects in socialization, self-expression and development of individuals. Therefore, physical education and sports should be remembered as important factors allowing the personality development and self-knowledge of individuals. One of the important factors here is education, for sure.

Education can be seen in a broad sense as a process that helps people believe in community behavior, moral and aesthetic measures and their healthy harmonization of sense of life (Mengütay, 2006: 1-144). The education that starts in the family after the child is born is sustained?? with the interaction between friends and through the mass media such as radio, television, cinema, theatre and artistic and literature works (Varış, 1994). The dissemination of education and the participation of sports in the school curriculum programs as well can positively affect the participation of the individuals in the sports. Likewise, "sociologists have found that, individuals widely participate in leisure time activities when the education level increases. Education also makes individuals open to the society through socializing them" and increases their tendency to participate in the fields of social activity. Sports can also become a subject for those who are socialized or increasingly inclined to socialize (Kongar, 1993: 1-207.).

Sports is an aesthetic, technical, physical, competitive and social process based on the use of main skills and the battling methods with or without tools developed by people while fighting with nature alone or all together peacefully and through simulation for games, distraction and a getaway from work in parallel to the increase in leisure time (Taşmektepligil, 1995; Fişek, 1998).

In modern life, sports is accepted as an integral part of the planned studies suggested by the pedagogues in order to ensure the personality formation and development of individual capabilities and is increasing its importance day by day (Fişek, 1998). According 


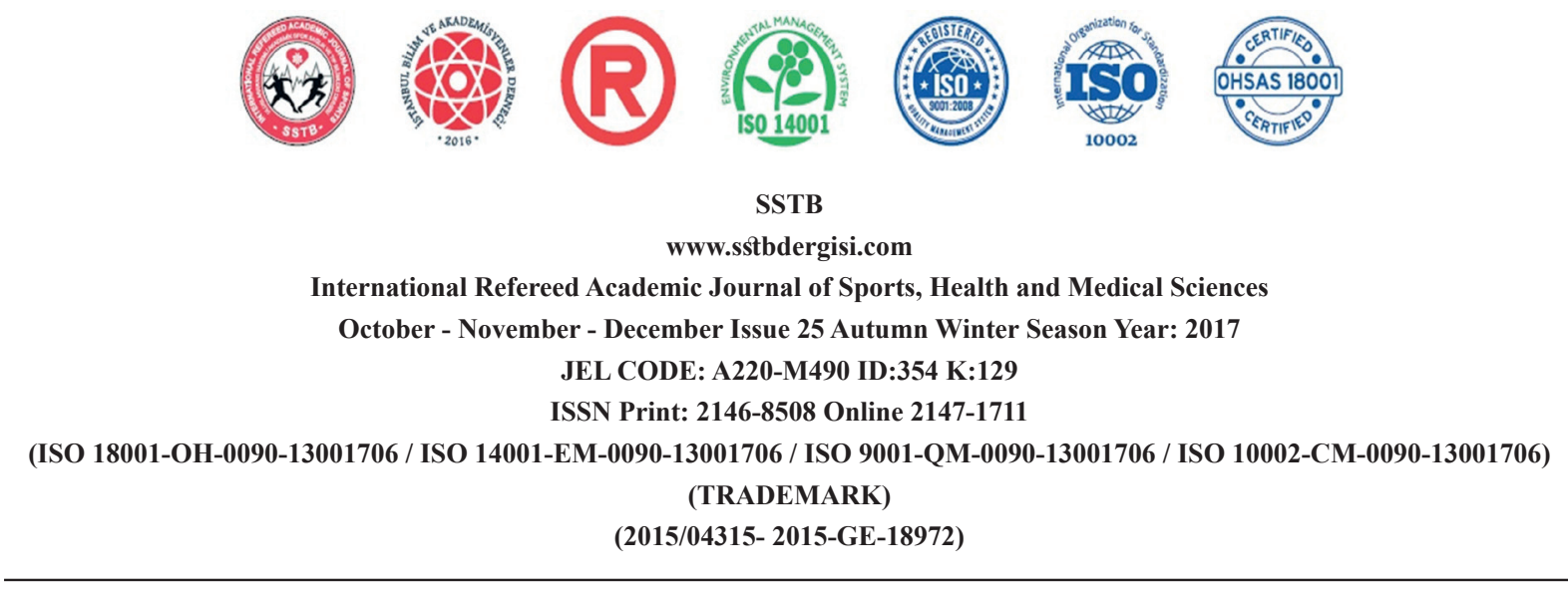

to basic principles of the National Education, physical education means ensuring the physical, mental and intellectual development of individuals. The fact that individuals live in accordance with the social rules is related to being able to give a good example of relations with each other, being helpful, smart, physically and mentally healthy and showing respect to human rights. Physical education plays a big role in socialization of individuals and helping them find their personality and lead on a straight line (Özbayraktar vd., 2008).

In the sport environment, individuals learn to recognize their own talents and the talents of others, to compete on equal conditions, to appreciate others by accepting defeat, to be modest when they win, to help others and to optimize their time and effort by competing with nature and time. In this regard, sports are an important tool of modern education system that aims to prepare a person for life in a versatile way (Fişek, 1998). Very hardworking individuals get the result in sports just like in education. The difference between those who have adopted sports as a lifestyle and those avoiding sports can only be removed with education. Although it is not possible for everyone to turn to the sport with the same enthusiasm and excitement, it is not impossible to raise the pleasure of doing sports to a certain level. Development of sports potential can only be ensured with a systematic education. Since cultural change will improve the values of the community in a positive way, directing towards sports by taking others as an example can reach to significant dimensions (İnal, 2003).

The factor having the highest effect on individual is environment in family, childhood, adolescence and even in early life. Its effect may decrease a bit from childhood to youth. The reason isn't the reduced interest shown by family towards children. In adolescence and youth, individuals tend towards environment apart from family (Öztürk, 1998: 61). Groups of friends are generally composed of the individuals with the same socio-economic and cultural structure. This shows that the young people with lots of things in common get together. In team friendships of sports branches, the common feature is observed to be the sports skills possessed regarding the failure of these rules (Karasüleymenoğlu, 1995). Turning towards a place, a thing, a person or an event means choosing it as a purpose, adopting it, taking care of it and devoting oneself to it (İnal, 2003; Cited from Büyük Larousse, 1986: İkizler and Tekin, 2008: 29). Guidance is the organization process of the elements required to produce a more productive work in relation to the work to be done. These elements may differ depending on the fields to be guided. The most effective way 


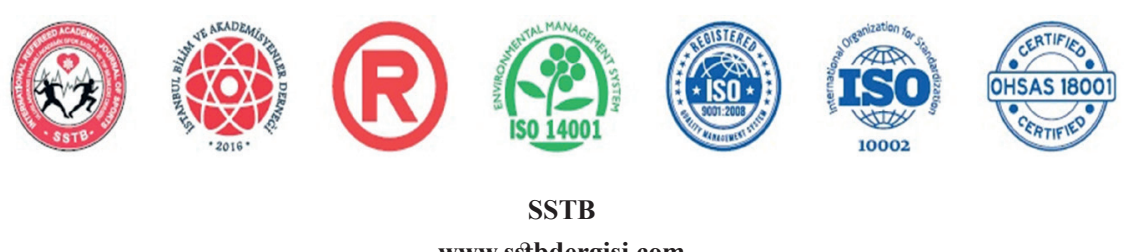

www.sstbdergisi.com

International Refereed Academic Journal of Sports, Health and Medical Sciences

October - November - December Issue 25 Autumn Winter Season Year: 2017

JEL CODE: A220-M490 ID:354 K:129

ISSN Print: 2146-8508 Online 2147-1711

(ISO 18001-OH-0090-13001706 / ISO 14001-EM-0090-13001706 / ISO 9001-QM-0090-13001706 / ISO 10002-CM-0090-13001706) (TRADEMARK)

(2015/04315- 2015-GE-18972)

to guide people is interaction. Interaction exercises control over people. The stronger the interaction is, the more powerful guidance becomes (Kılc1gil, 1998: 1-169.).

Youth's leisure-time tendencies sometimes do not meet the demands of their families, which leads to generation conflicts. While families have been of the opinion that the activities not requiring spending money and doing homework should be done in leisure times not doing sports or watching TV and listening to the radio, it is observed that they give up this thought and agree on doing such activities as sports together with the social development in time. Because sports plays important roles in the socialization of the individual, parents are not left out of the sports phenomenon allowing children be more social (Öztürk, 1998: 61).

The common idea in our society that sports negatively affects academic success and causes injuries is one of the factors causing parents to have a negative attitude for the participation in physical education and sports activities. Although there is no clear finding that the sports affects academic achievement negatively, it has been found in many studies that participation in physical education and sports activities has positive effects on academic achievement on the contrary. However, the lack of awareness and the inability of the education system to allow for the academ- ic and sports life together cause families to get negative ideas in this matter (DPT, 1983; Güven ve Öncü, 2006: 81-90). Today, families approach to sports more positively when compared to past and direct their children towards sports. Currently there are families who think that sports activities prevent the child from succeeding in the classroom but many families also register their children for sports courses by paying a certain fee (Öztürk, 1998: 61).

School is the most effective social institution in education of individuals. Education is a social institution and organized community being the most effective factor in efficient work of people and country's development and not abandoned by any population. School community is composed of managers, educators and students. School brings success to working law and people of the country (Öztürk, 1998).

Volleyball comes at the forefront of sports that can be used by educators to raise children and youth as good people. Because the only group sport closed to violence is volleyball (Fröhner, 1999). Volleyball is a sport characterized by maximal effort, team work and close interaction of deep harmony. The concept of team work refers to the cooperation of a group of people for a common target universally. Cooperation is in every part of life and an important element of each achievement (Bengü, 1987: 1-144). 


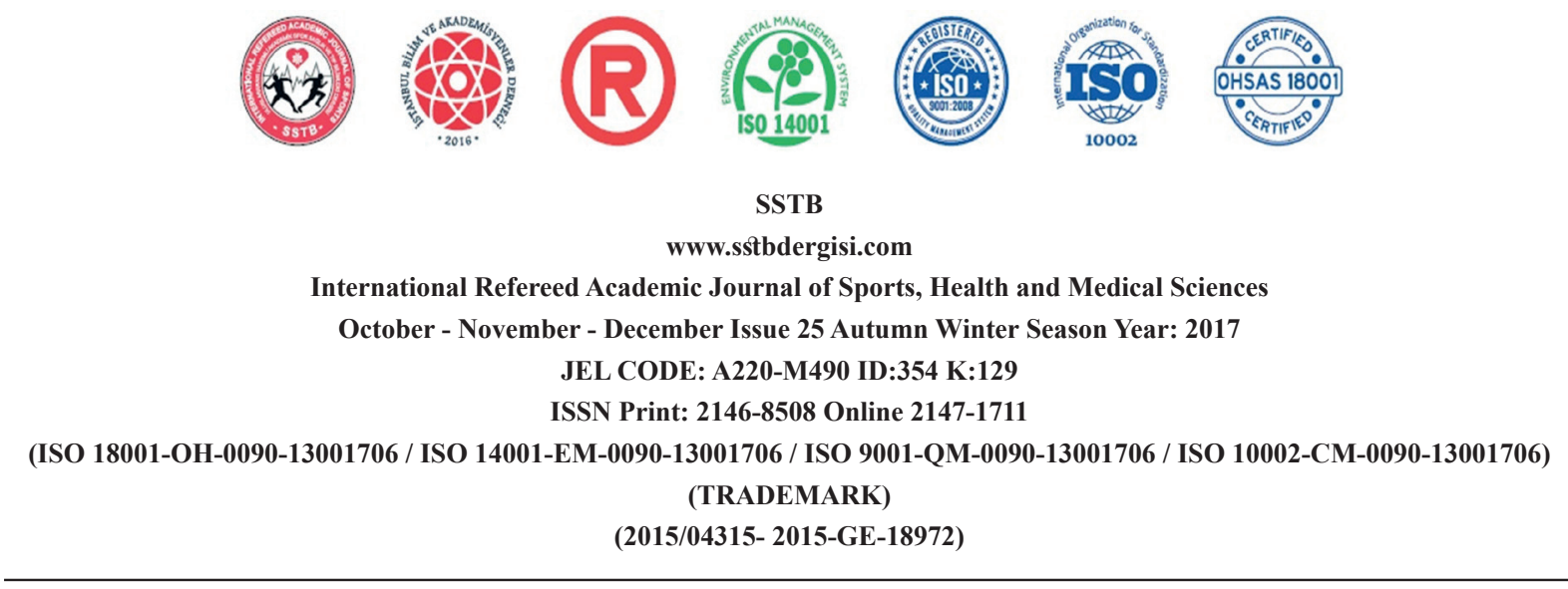

Within the scope of sport project on campus, the purpose is to determine the factors affecting the preferences of individuals for volleyball and the effect of family and society factors. The aim is here to determine whether the attitudes of families of individuals preferring volleyball towards the sport and the branch selected, the expectations of individual in volleyball, the reasons being effective in selection of branches differ by the personal information of individuals, the existence of an individual doing sports in family and by sex. The purpose of this study is to determine the effect of family and society factors on individuals preferring and doing volleyball on campus.

\section{MATERIAL and METHOD}

The survey method was used in the research, analyses were performed by using data obtained from the individuals who preferred volleyball.

This method was used due to the fact that the purpose was to analyze the reasons of individuals for starting volleyball, the reasons affecting the selection of volleyball branch, the attitude of families towards volleyball, the expectations of families from volleyball, the opportunities on campus and their disponibility and their goals about volleyball in terms of family, society and the different variables in their personal information. Questionnaires that were previously used as information col- lection tool with the tested necessity and reliability were used as the data collection tool.

\section{Population and Sample}

The research group is composed of female and male students preferring volleyball on campus of Frrat University. Survey model was used in the research and the questionnaire was applied for the purpose of data collection. 103 individual participated in the 23-question survey and a total of 97 surveys were evaluated after faulty and missing ones were excluded.

\section{Data Collection and Analysis}

Questionnaires that were previously used as information collection tool with the tested necessity and reliability were used as the data collection tool. The questionnaire applied to individuals is related to effect of their personal information, opinions about being a volleyball player, campus, family and society factors. The questionnaire was taken from the master's thesis of Seher Aslan Esen titled "the reasons for the preferences of students studying in primary schools to be a volleyball player and the effect of school, family and society factors" prepared in Marmara University Institute of Educational Sciences Department of Physical Education and Sports in 2010 (26). The questionnaire was distributed by the researcher during the volleyball training programs on campus of Firat University. 


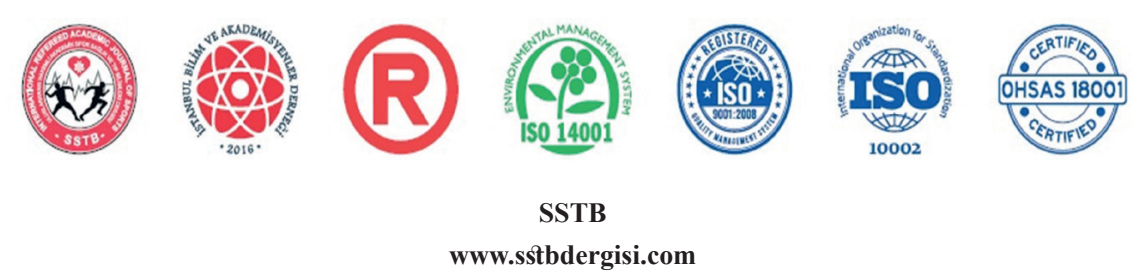

International Refereed Academic Journal of Sports, Health and Medical Sciences

October - November - December Issue 25 Autumn Winter Season Year: 2017

JEL CODE: A220-M490 ID:354 K:129

ISSN Print: 2146-8508 Online 2147-1711

(ISO 18001-OH-0090-13001706 / ISO 14001-EM-0090-13001706 / ISO 9001-QM-0090-13001706 / ISO 10002-CM-0090-13001706) (TRADEMARK)

(2015/04315- 2015-GE-18972)

The reason for application of questionnaire was explained and the survey was applied after the individuals were informed about how to fill the survey. The questionnaires were collected by the researcher.

SPSS 21.0 package program was used for the statistical solutions. Chi-square, frequency and percentage tests were applied as the statistical activity. The significance level was taken as $\mathrm{p}<0.05$ '.

\section{RESULTS}

Table 1. Demographic Information of Research Group

\begin{tabular}{|c|c|c|c|}
\hline VARIABLES & & $\mathbf{N}$ & $\%$ \\
\hline \multirow{3}{*}{ Sex } & Female & 56 & 57.7 \\
\hline & Male & 41 & 42.3 \\
\hline & Total & 97 & 100 \\
\hline \multirow{3}{*}{ Age } & 20 and below & 30 & 30.9 \\
\hline & $21-23$ & 50 & 51.5 \\
\hline & 24 and above & 17 & 17.5 \\
\hline \multirow{3}{*}{ Height } & $160 \mathrm{~cm}$ and below & 17 & 17.5 \\
\hline & $161 \mathrm{~cm}-166 \mathrm{~cm}$ & 24 & 24.7 \\
\hline & $167 \mathrm{~cm}$ and above & 56 & 57.7 \\
\hline \multirow{4}{*}{ Weight } & $55 \mathrm{~kg}$ and below & 37 & 38.1 \\
\hline & $56 \mathrm{~kg}-61 \mathrm{~kg}$ & 27 & 27.8 \\
\hline & $62 \mathrm{~kg}-67 \mathrm{~kg}$ & 20 & 20.6 \\
\hline & $68 \mathrm{~kg}$ and above & 13 & 13.4 \\
\hline
\end{tabular}

According to the research data, $57.7 \%$ of the individuals preferring volleyball on campus are women and $42.3 \%$ of them are men. The percentage of those aged 20 and below is $30.9 \%, 51.5 \%$ is aged between 21 and 23 , $17.5 \%$ is aged 24 and above.

Concerning the height ratios of individuals, $17.5 \%$ is $160 \mathrm{~cm}$ and shorter, $24.7 \%$ is be- tween $161 \mathrm{~cm}-166 \mathrm{~cm}$ tall, $57.7 \%$ is $167 \mathrm{~cm}$ and taller.

Regarding the weights of individuals, the weight of $38.1 \%$ is $55 \mathrm{~kg}$ and less,

$27.8 \%$ weighs between $56 \mathrm{~kg}$ and $61 \mathrm{~kg}$, $20.6 \%$ weighs between $62 \mathrm{~kg}-67 \mathrm{~kg}$ and the weight of $13.4 \%$ is $68 \mathrm{~kg}$ and more. 


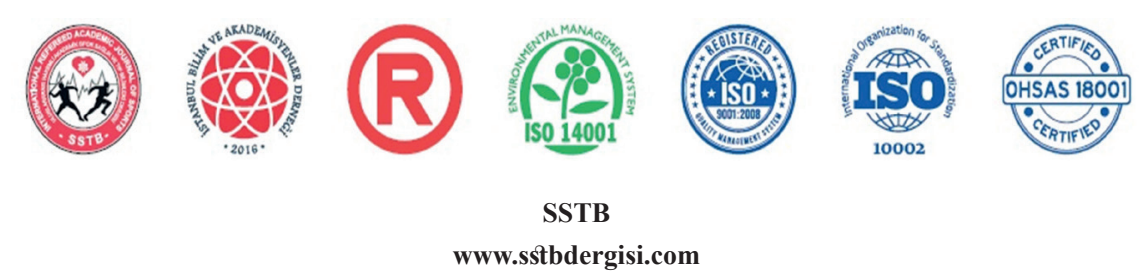

International Refereed Academic Journal of Sports, Health and Medical Sciences

October - November - December Issue 25 Autumn Winter Season Year: 2017

JEL CODE: A220-M490 ID:354 K:129

ISSN Print: 2146-8508 Online 2147-1711

(ISO 18001-OH-0090-13001706 / ISO 14001-EM-0090-13001706 / ISO 9001-QM-0090-13001706 / ISO 10002-CM-0090-13001706)

(TRADEMARK)

(2015/04315- 2015-GE-18972)

Table 2. Table on The Reasons for Preference of Individuals for Volleyball and The Factors of Family and Society

\begin{tabular}{|c|c|c|c|}
\hline VARIABLES & & $\mathbf{N}$ & $\%$ \\
\hline \multirow{5}{*}{ Where did you first play volleyball? } & Primary School & 23 & 23.7 \\
\hline & Secondary School & 10 & 10.3 \\
\hline & High School & 26 & 26.8 \\
\hline & University & 37 & 38.1 \\
\hline & Sports Club & 1 & 1.0 \\
\hline \multirow{3}{*}{$\begin{array}{l}\text { Are there anyone else doing sports in } \\
\text { your family? }\end{array}$} & Father & 1 & 1.0 \\
\hline & Sibling & 45 & 46.4 \\
\hline & None of them & 51 & 52.6 \\
\hline \multirow{4}{*}{$\begin{array}{l}\text { Who has a share in your preference } \\
\text { for volleyball? }\end{array}$} & Family & 4 & 4.1 \\
\hline & Friends & 29 & 29.9 \\
\hline & Teachers & 53 & 54.6 \\
\hline & Famous Athletes & 11 & 11.3 \\
\hline \multirow{3}{*}{$\begin{array}{l}\text { Who affected you most in choosing } \\
\text { volleyball aside from the family mem- } \\
\text { bers? }\end{array}$} & Physical Education Teacher & 68 & 70.1 \\
\hline & Friend & 26 & 26.8 \\
\hline & Close relative - aunt, uncle etc. & 3 & 3.1 \\
\hline \multirow{4}{*}{$\begin{array}{l}\text { Does your family support you positi- } \\
\text { vely for doing sports? }\end{array}$} & Always & 66 & 68.0 \\
\hline & Sometimes & 25 & 25.8 \\
\hline & Frequently & 3 & 3.1 \\
\hline & Never & 3 & 3.1 \\
\hline \multirow{4}{*}{$\begin{array}{l}\text { Do your household follow any news- } \\
\text { papers, magazines and TV programs } \\
\text { about sports? }\end{array}$} & Always & 42 & 43.3 \\
\hline & Sometimes & 36 & 37.1 \\
\hline & Frequently & 10 & 10.3 \\
\hline & Never & 9 & 9.3 \\
\hline \multirow{4}{*}{$\begin{array}{l}\text { Is your family of the opinion that } \\
\text { sports negatively affect you? }\end{array}$} & Always & 8 & 8.2 \\
\hline & Sometimes & 41 & 42.3 \\
\hline & Frequently & 2 & 2.1 \\
\hline & Never & 46 & 47.4 \\
\hline
\end{tabular}


 \\ SSTB \\ www.sstbdergisi.com}

International Refereed Academic Journal of Sports, Health and Medical Sciences

October - November - December Issue 25 Autumn Winter Season Year: 2017

JEL CODE: A220-M490 ID:354 K:129

ISSN Print: 2146-8508 Online 2147-1711

(ISO 18001-OH-0090-13001706 / ISO 14001-EM-0090-13001706 / ISO 9001-QM-0090-13001706 / ISO 10002-CM-0090-13001706) (TRADEMARK)

(2015/04315- 2015-GE-18972)

\begin{tabular}{|c|c|c|c|}
\hline \multirow{4}{*}{$\begin{array}{l}\text { Which fields you can do sports in } \\
\text { your neighborhood? }\end{array}$} & Sport facility & 34 & 35.1 \\
\hline & Schoolyard & 25 & 25.8 \\
\hline & Neighborhood & 18 & 18.6 \\
\hline & None of them & 20 & 20.6 \\
\hline \multirow{4}{*}{ How often do you use these fields? } & Always & 11 & 11.3 \\
\hline & Sometimes & 56 & 57.7 \\
\hline & Mostly & 15 & 15.5 \\
\hline & Never & 15 & 15.5 \\
\hline \multirow{5}{*}{$\begin{array}{l}\text { How often are the sports activities } \\
\text { organized on campus? }\end{array}$} & Barely & 42 & 43.3 \\
\hline & Rarely & 15 & 15.5 \\
\hline & Sometimes & 22 & 22.7 \\
\hline & Generally & 10 & 10.3 \\
\hline & Frequently & 8 & 8.2 \\
\hline \multirow{5}{*}{$\begin{array}{l}\text { Are there sufficient equipment and } \\
\text { field for volleyball on campus? }\end{array}$} & Barely & 32 & 33.0 \\
\hline & Rarely & 16 & 16.5 \\
\hline & Sometimes & 28 & 28.9 \\
\hline & Generally & 18 & 18.6 \\
\hline & Frequently & 3 & 3.1 \\
\hline \multirow{5}{*}{$\begin{array}{l}\text { How is the success of sports teams } \\
\text { and the importance attached to athle- } \\
\text { tes on campus? }\end{array}$} & Little & 27 & 27.8 \\
\hline & A little & 11 & 11.3 \\
\hline & Moderate & 29 & 29.9 \\
\hline & Good & 24 & 24.7 \\
\hline & Great & 6 & 6.2 \\
\hline \multirow{2}{*}{$\begin{array}{l}\text { Do you play volleyball as a licensed } \\
\text { player in any club? }\end{array}$} & Yes & 12 & 12.4 \\
\hline & No & 85 & 87.6 \\
\hline \multirow{5}{*}{$\begin{array}{l}\text { What are your future objectives for } \\
\text { volleyball? }\end{array}$} & Being a national athlete & 2 & 2.1 \\
\hline & Earning money & 6 & 6.2 \\
\hline & Being a coach & 42 & 43.3 \\
\hline & Being a physical education teacher & 29 & 29.9 \\
\hline & Other & 18 & 18.6 \\
\hline
\end{tabular}




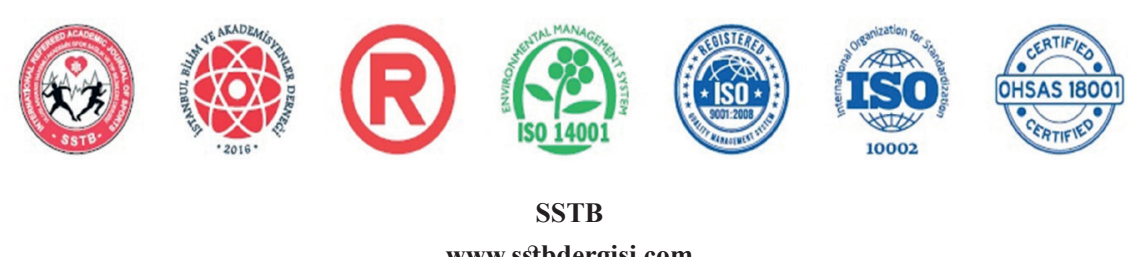

www.sstbdergisi.com

International Refereed Academic Journal of Sports, Health and Medical Sciences

October - November - December Issue 25 Autumn Winter Season Year: 2017

JEL CODE: A220-M490 ID:354 K:129

ISSN Print: 2146-8508 Online 2147-1711

(ISO 18001-OH-0090-13001706 / ISO 14001-EM-0090-13001706 / ISO 9001-QM-0090-13001706 / ISO 10002-CM-0090-13001706)

(TRADEMARK)

(2015/04315- 2015-GE-18972)

$23.7 \%$ of the participants of research started volleyball in primary school, $10.3 \%$ started in secondary school, $26.8 \%$ started in high school, $38.1 \%$ started to play in university and $1.0 \%$ started in a sports club.

Concerning the question 'Are there anyone else doing sports in your family?', $1.0 \%$ of the participants replied as father, $46.4 \%$ said sibling, $52.6 \%$ said none of them.

Regarding the responses given by the participants to the question 'Who has a share in your preference for volleyball?', $4.1 \%$ said family, $29.9 \%$ said friends, $54.6 \%$ said teachers, $11.3 \%$ said famous athletes.

The responses given to the question 'Who affected you most in choosing volleyball aside from the family members?' are as follows; $70.1 \%$ said physical education teacher, $26.8 \%$ said friends, $3.1 \%$ said close relatives such as uncle, aunt etc.

Concerning the responses given to the question 'Does your family support you positively for doing sports?', $68.0 \%$ said always, $25.8 \%$ said sometimes, $3.1 \%$ said frequently and $3.1 \%$ said never.

The responses given to the question 'Do your household follow any newspapers, magazines and TV programs about sports?' are as follows; $43.3 \%$ said always, $37.1 \%$ said sometimes, $10.3 \%$ said frequently, $9.3 \%$ said never.

The responses given to the question 'Is your family of the opinion that sports negatively affect you?' are as follows; $8.2 \%$ said always, $42.3 \%$ said sometimes, $2.1 \%$ said frequently and $47.4 \%$ said never.

Regarding the responses given to the question 'Which fields you can do sports in your neighborhood?', 35.1\% said sports facility, $25.8 \%$ said schoolyard, $18.6 \%$ said neighborhood, $20.6 \%$ said none of them.

The responses given to the question 'How often do you use these fields?' are as follows; $11.3 \%$ said always, $57.7 \%$ said sometimes, $15.5 \%$ said mostly and $15.5 \%$ said never.

Concerning the responses given to the question 'How often are the sports activities organized on campus?', $43.3 \%$ said barely, $15.5 \%$ said rarely, $22.7 \%$ said sometimes, $10.3 \%$ said generally and $8.2 \%$ said frequently.

The responses given to the question 'Are there sufficient equipment and field for volleyball on campus?' are as follows; $33.0 \%$ said barely, $16.5 \%$ said rarely, $28.9 \%$ said sometimes, $18.6 \%$ said generally and $3.1 \%$ said frequently.

Regarding the responses given to the question 'How is the success of sports teams and the importance attached to athletes on campus?', 


\section{(2)
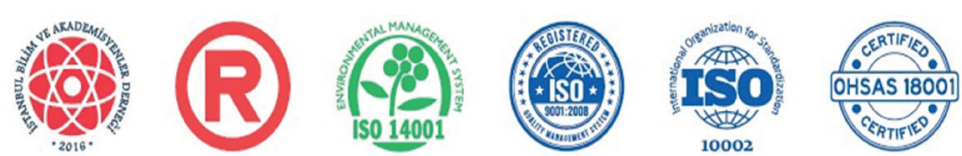 \\ SSTB \\ www.sstbdergisi.com}

International Refereed Academic Journal of Sports, Health and Medical Sciences

October - November - December Issue 25 Autumn Winter Season Year: 2017

JEL CODE: A220-M490 ID:354 K:129

ISSN Print: 2146-8508 Online 2147-1711

(ISO 18001-OH-0090-13001706 / ISO 14001-EM-0090-13001706 / ISO 9001-QM-0090-13001706 / ISO 10002-CM-0090-13001706) (TRADEMARK)

(2015/04315- 2015-GE-18972)

$27.8 \%$ said little, $11.3 \%$ said a little, $29.9 \%$ said moderate, $24.7 \%$ said good and $6.2 \%$ said great.

The responses given to the question 'Do you play volleyball as a licensed player in any club?' are as follows; $12.4 \%$ said yes and $87.6 \%$ said no.
The responses given to the question 'What are your future objectives for volleyball?' are as follows; $2.1 \%$ played volleyball for being a national athlete, $6.2 \%$ for earning money, $43.3 \%$ for being a coach, $29.9 \%$ for being a physical education teacher and $18.6 \%$ for other reasons.

Table 3. Findings Related To Whether Families Support Their Children Positively About Playing Volleyball

\begin{tabular}{|c|c|c|c|c|c|}
\hline & & & \multicolumn{2}{|c|}{ Sex } & \multirow[t]{2}{*}{ Total } \\
\hline & & & Female & Male & \\
\hline \multirow{8}{*}{$\begin{array}{l}\text { Does your family support you in } \\
\text { playing volleyball positively? }\end{array}$} & \multirow[t]{2}{*}{ Always } & Number & 37 & 29 & 66 \\
\hline & & Total percentage & 38.1 & 27.9 & $66 \%$ \\
\hline & \multirow[t]{2}{*}{ Sometimes } & Number & 16 & 9 & 25 \\
\hline & & Total percentage & 14.4 & 10.6 & $25 \%$ \\
\hline & \multirow[t]{2}{*}{ Frequently } & Number & 1 & 2 & 3 \\
\hline & & Total percentage & 1.7 & 1.3 & $3 \%$ \\
\hline & \multirow[t]{2}{*}{ Never } & Number & 2 & 1 & 3 \\
\hline & & Total percentage & 1.7 & 1.3 & $3 \%$ \\
\hline \multirow[t]{2}{*}{ Total } & & Number & 56 & 41 & 97 \\
\hline & & Total & $57.7 \%$ & $42.3 \%$ & $100 \%$ \\
\hline Chi-Square Tests & & $\begin{array}{l}\text { Asymp. Sig. } \\
\text { (2-sided) }\end{array}$ & .727 & & \\
\hline
\end{tabular}

It has been observed that families approach to their children's doing sports positively all the time $(66 \%)$, sigma value has been observed to be $\mathrm{p}<0.05 ; .727$ following the Chi-Square test and no significant difference has been found between sexes. 


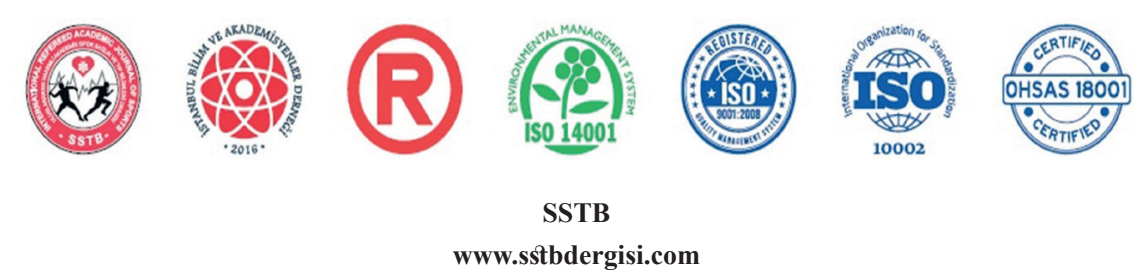

International Refereed Academic Journal of Sports, Health and Medical Sciences

October - November - December Issue 25 Autumn Winter Season Year: 2017

JEL CODE: A220-M490 ID:354 K:129

ISSN Print: 2146-8508 Online 2147-1711

(ISO 18001-OH-0090-13001706 / ISO 14001-EM-0090-13001706 / ISO 9001-QM-0090-13001706 / ISO 10002-CM-0090-13001706) (TRADEMARK)

(2015/04315- 2015-GE-18972)

Table 4. Findings About The Relation Of The Question 'Who Has A Share In Your Preference For Volleyball?' With Sex

\begin{tabular}{|c|c|c|c|c|c|}
\hline & & & \multicolumn{2}{|c|}{ Sex } & \multirow{2}{*}{ Total } \\
\hline & & & Female & Male & \\
\hline \multirow{8}{*}{$\begin{array}{l}\text { Who has a share in your pre- } \\
\text { ference for volleyball? }\end{array}$} & \multirow[t]{2}{*}{ Family } & Number & 3 & 1 & 4 \\
\hline & & Total percentage & $2.3 \%$ & $1.7 \%$ & $4.1 \%$ \\
\hline & \multirow[t]{2}{*}{ Friends } & Number & 17 & 12 & 29 \\
\hline & & Total percentage & $16.7 \%$ & $12.3 \%$ & $29.9 \%$ \\
\hline & \multirow[t]{2}{*}{ Teachers } & Number & 29 & 24 & 53 \\
\hline & & Total percentage & $30.6 \%$ & $22.4 \%$ & $54.6 \%$ \\
\hline & \multirow{2}{*}{$\begin{array}{l}\text { Famous ath- } \\
\text { letes }\end{array}$} & Number & 7 & 4 & 11 \\
\hline & & Total percentage & $6.4 \%$ & $4.6 \%$ & $11.3 \%$ \\
\hline \multirow[t]{2}{*}{ Total } & & Number & 56 & 41 & 97 \\
\hline & & Total & $57.7 \%$ & $42.3 \%$ & $100 \%$ \\
\hline Chi-Square Tests & & $\begin{array}{l}\text { Asymp. Sig. } \\
\text { (2-sided) }\end{array}$ & .837 & & \\
\hline
\end{tabular}

It has been observed that teachers are effective in branch selection of individuals for volleyball with a rate of $54.6 \%$; sigma value has been observed to be $\mathrm{p}<0.05$;
.837 following the Chi-Square test and no significant difference has been found between sexes. 
Table 5. Findings About The Relation Between The Questions 'Who Affected You Most In Choosing Volleyball Aside From The Family Members' And 'Where Did You First Play Volleyball?'

\begin{tabular}{|c|c|c|c|c|c|c|}
\hline & & & \multicolumn{3}{|c|}{$\begin{array}{l}\text { Who affected you most in choosing vol- } \\
\text { leyball aside from the family members? }\end{array}$} & \multirow{2}{*}{ Tota } \\
\hline & & & $\begin{array}{l}\text { Physical } \\
\text { education } \\
\text { teachers }\end{array}$ & Friends & $\begin{array}{l}\text { Close relatives } \\
\text { such as uncle, } \\
\text { aunt etc. }\end{array}$ & \\
\hline \multirow{10}{*}{$\begin{array}{l}\text { Where did you } \\
\text { first play volley- } \\
\text { ball? }\end{array}$} & \multirow{2}{*}{$\begin{array}{l}\text { Primary } \\
\text { school }\end{array}$} & Number & 16 & 6 & 1 & 23 \\
\hline & & $\begin{array}{l}\text { Total percen- } \\
\text { tage }\end{array}$ & 16.1 & 6.2 & .7 & 23.0 \\
\hline & \multirow{2}{*}{$\begin{array}{l}\text { Secondary } \\
\text { school }\end{array}$} & Number & 5 & 5 & 0 & 10 \\
\hline & & $\begin{array}{l}\text { Total percen- } \\
\text { tage }\end{array}$ & 7.0 & 2.7 & .3 & 10.0 \\
\hline & \multirow[t]{2}{*}{ High school } & Number & 20 & 6 & 0 & 26 \\
\hline & & $\begin{array}{l}\text { Total percen- } \\
\text { tage }\end{array}$ & 18.2 & 7.0 & .8 & 26.0 \\
\hline & \multirow[t]{2}{*}{ University } & Number & 26 & 9 & 2 & 37 \\
\hline & & $\begin{array}{l}\text { Total percen- } \\
\text { tage }\end{array}$ & 25.9 & 9.9 & 1.1 & 37.0 \\
\hline & \multirow[t]{2}{*}{ Sports club } & Number & 1 & 0 & 0 & 1 \\
\hline & & $\begin{array}{l}\text { Total percen- } \\
\text { tage }\end{array}$ & .7 & .3 & .0 & 1.0 \\
\hline \multirow[t]{2}{*}{ Total } & & Number & 68 & 26 & 3 & 97 \\
\hline & & Total & 70.1 & 26.8 & 3.1 & 100 \\
\hline Chi-Square Tests & & \multicolumn{3}{|c|}{ Asymp. Sig. (2-sided) } & .727 & \\
\hline
\end{tabular}

It has been observed that $25.9 \%$ of the individuals start playing volleyball in university and $18.2 \%$ starts in high school for the first time aside from the family members, physical education teachers have the highest effect; sigma value has been found to be $\mathrm{p}<0.05 ; .727$ following the Chi-Square test and no significant difference has been found. 


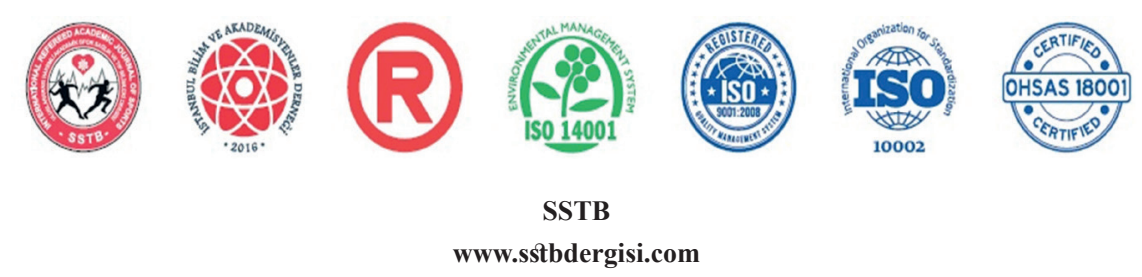

International Refereed Academic Journal of Sports, Health and Medical Sciences October - November - December Issue 25 Autumn Winter Season Year: 2017

JEL CODE: A220-M490 ID:354 K:129

ISSN Print: 2146-8508 Online 2147-1711

(ISO 18001-OH-0090-13001706 / ISO 14001-EM-0090-13001706 / ISO 9001-QM-0090-13001706 / ISO 10002-CM-0090-13001706) (TRADEMARK)

(2015/04315- 2015-GE-18972)

Table 6. Findings About The Relation Between The Questions 'Who Affected You Most In Choosing Volleyball Aside From The Family Members?' And 'Who Has A Share In Your Preference For Volleyball?'

\begin{tabular}{|c|c|c|c|c|c|c|}
\hline & & & \multicolumn{3}{|c|}{$\begin{array}{l}\text { Who affected you most in choosing vol- } \\
\text { leyball aside from the family members? }\end{array}$} & \multirow[t]{2}{*}{ Total } \\
\hline & & & $\begin{array}{l}\text { Physical } \\
\text { education } \\
\text { teachers }\end{array}$ & Friends & $\begin{array}{l}\text { Close rela- } \\
\text { tives such } \\
\text { as uncle, } \\
\text { aunt etc. }\end{array}$ & \\
\hline \multirow{8}{*}{$\begin{array}{l}\text { Who has a } \\
\text { share in your } \\
\text { preference } \\
\text { for volley- } \\
\text { ball? }\end{array}$} & \multirow[t]{2}{*}{ Family } & Number & 2 & 1 & 1 & 4 \\
\hline & & $\begin{array}{l}\text { Total per- } \\
\text { centage }\end{array}$ & $2.8 \%$ & $1.1 \%$ & $.1 \%$ & $4.0 \%$ \\
\hline & \multirow[t]{2}{*}{ Friends } & Number & 15 & 14 & 0 & 29 \\
\hline & & $\begin{array}{l}\text { Total per- } \\
\text { centage }\end{array}$ & $20.3 \%$ & $7.8 \%$ & $.9 \%$ & $29.0 \%$ \\
\hline & \multirow[t]{2}{*}{ Teachers } & Number & 45 & 7 & 1 & 53 \\
\hline & & $\begin{array}{l}\text { Total per- } \\
\text { centage }\end{array}$ & $37.2 \%$ & $14.2 \%$ & $1.6 \%$ & $\mathbf{5 3 . 0} \%$ \\
\hline & \multirow[t]{2}{*}{ Famous athletes } & Number & 6 & 4 & 1 & 11 \\
\hline & & $\begin{array}{l}\text { Total per- } \\
\text { centage }\end{array}$ & $7.7 \%$ & $2.9 \%$ & $.3 \%$ & $11.0 \%$ \\
\hline \multirow{2}{*}{\multicolumn{2}{|c|}{ Total }} & Number & 68 & 26 & 3 & 97 \\
\hline & & Total & $70.1 \%$ & $26.8 \%$ & $3.1 \%$ & $100 \%$ \\
\hline \multicolumn{2}{|c|}{ Chi-Square Tests } & \multicolumn{3}{|c|}{ Asymp. Sig. (2-sided) } & .002 & \\
\hline
\end{tabular}

It has been observed that teachers are effective in branch selection of individuals for volleyball with a rate of $53.0 \%$ and friends are also effective with a rate of $29.0 \%$. Sigma value has been found to be $\mathrm{p}<0.05 ; .002$ following the Chi-Square test and this indicates that the result is significant.

\section{DISCUSSION}

In this paper, the differences between the reasons for the preferences of individuals for volleyball on campus and the effect of family and society factors have been analyzed.

The responses of the participant individuals for the question 'Who has a share in your preference for volleyball?' are as follows; 


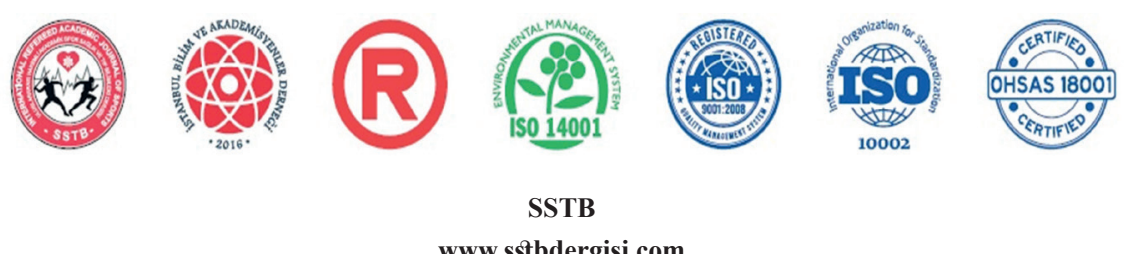

www.sstbdergisi.com

International Refereed Academic Journal of Sports, Health and Medical Sciences

October - November - December Issue 25 Autumn Winter Season Year: 2017

JEL CODE: A220-M490 ID:354 K:129

ISSN Print: 2146-8508 Online 2147-1711

(ISO 18001-OH-0090-13001706 / ISO 14001-EM-0090-13001706 / ISO 9001-QM-0090-13001706 / ISO 10002-CM-0090-13001706) (TRADEMARK)

(2015/04315- 2015-GE-18972)

$4.1 \%$ said family and $54.6 \%$ said teachers. This condition shows similarity with the study of Esen (2010: 53).

The responses of the participant individuals for the question 'Who affected you most in choosing volleyball aside from the family members?' are physical education teachers from $70.1 \%$ and close relatives such as uncle, aunt etc. with 3.1\%; This condition is similar to the study of Esen (2010: 53) (physical education teacher with the highest rate of $34.2 \%$ ).

Regarding the question 'Are there sufficient amount of fields and equipment about volleyball in the campus?', $33.0 \%$ of the participant individuals have responded as little and this condition is similar to the study of Göktaş (1994: 35) titled as the effect of family on directing towards sports in which it has been determined that the first problem of the students concerning the participation in athletic activities is the inadequacy of facility's equipment. It is also similar to the study of Dalkıran et al. (2004: 14) titled the opinions of the physical education teachers working at public and private primary and secondary schools of Ankara province concerning the effective use of indoor sports facilities in extra-curricular activities, $100 \%$ of the physical education teachers agree with the opinion 'facility's equipment is highly important in performing the physical education activities appropriately'.
The responses of the participant individuals for the question 'Does your family support you positively for doing sports?' are as follows; $68.0 \%$ said always and this condition complies with the study of Esen (2010: 54).

The participant individuals have responded to the question 'Do your household follow any newspapers, magazines and TV programs about sports?' as always with $43.3 \%$ and this condition shares similarities with the study of Esen (2010: 54).

The responses of the participant individuals for the question 'Is your family of the opinion that sports negatively affect you?' are as follows; $42.3 \%$ said sometimes and $47.4 \%$ said never and it has been observed that the effect of society on directing individuals towards sports is high. This condition shares similarities with the study of Esen (2010). In the study of Yildiz (2015: 79) titled the analysis on socialization and happiness level of university students doing and not doing sports, it is observed that the secondary schools the students studying in the School of Physical Education and Sports have graduated, class levels and education and income levels of parents are effective on their socialization; their sex, personal communication and level of satisfaction from life cause an increase in their happiness, so it has been concluded that sports is an effective tool in socialization of individuals and increasing their happiness 


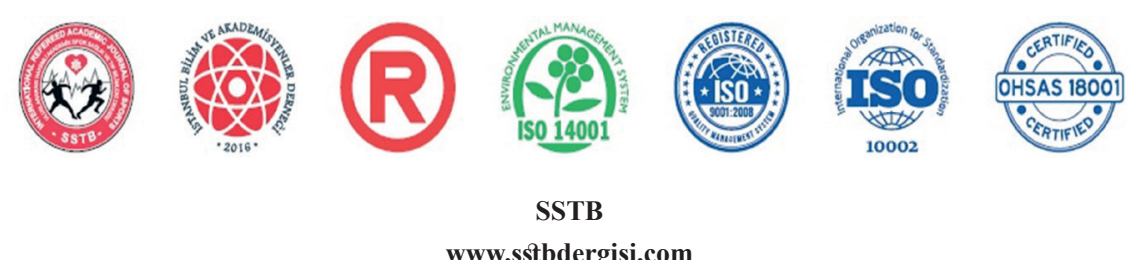

www.sstbdergisi.com

International Refereed Academic Journal of Sports, Health and Medical Sciences

October - November - December Issue 25 Autumn Winter Season Year: 2017

JEL CODE: A220-M490 ID:354 K:129

ISSN Print: 2146-8508 Online 2147-1711

(ISO 18001-OH-0090-13001706 / ISO 14001-EM-0090-13001706 / ISO 9001-QM-0090-13001706 / ISO 10002-CM-0090-13001706)

(TRADEMARK)

(2015/04315- 2015-GE-18972)

and the most of the families (47.4\%) support the idea that sports doesn't affect individuals negatively.

It has been determined that individuals are affected from the physical education teachers more; teachers are effective in preferences of individuals for volleyball with a rate of $53.0 \%$; in addition, friends are also effective with a rate of $29.0 \%$. Sigma value has been observed to be $\mathrm{p}<0.05 ; .002$ following the Chi-Square test and it indicates that the result is significant.

Although the rate of individuals doing sports in the families of the participant individuals isn't so low (47.4\%), their families support them more in doing sports $(68.0 \%)$. This indicates that families positively encourage the individuals to do sports.

\section{CONCLUSION}

It has been established that especially teachers provide positive effect to students in playing volleyball. It is thought that the inadequacy of sports materials and facility on campus negatively affect individuals.

\section{Suggestions}

By working in cooperation with the companies, institutions and organization that are engaged in sports, the awareness of families can be raised concerning the benefits of the participation in sports and sports activities and some projects can be held to direct individuals towards these activities.

The necessary interest should be paid to volleyball in mass media and informative and instructive broadcasts can be organized for this sport.

The sport institutions and organizations in the society should conduct the necessary studies to guide the families to the sport and should aim at the rule of doing sports for a healthy life of families and should help meeting the needs for the material, field, coach and physical education teachers being among the obstacles in front of sports.

Existing sports opportunities on campus should be improved, maintenance and repairs of sports fields should be made and the required studies should be performed to help individuals do sports in healthy environments and get the maximum benefit.

\section{REFERENCES}

BENG ̈̈, M., (1987). Voleybol, Adam Yayınları, İstanbul, ss.1-144

B $\ddot{U} Y \ddot{U} K$ LAROUSSE, (1986). Cilt 20, İstanbul

CENGIZ, R., TAŞMEKTEPLIGIL, M., (2016). Spor üzerine sosyolojik bir çözümleme: spor merkezleri (Samsun ör- 


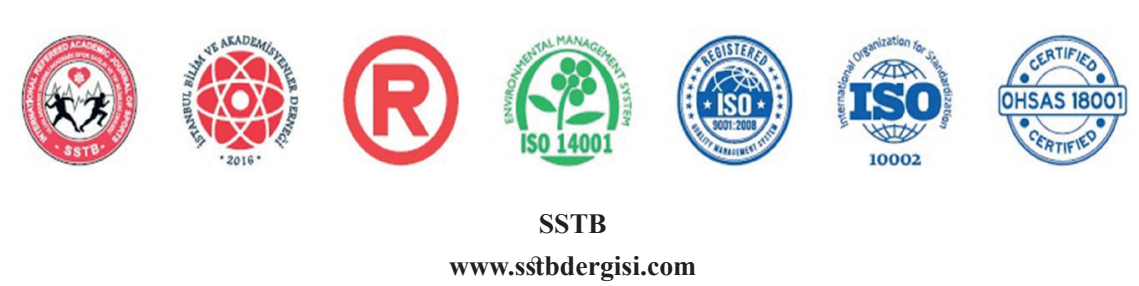

International Refereed Academic Journal of Sports, Health and Medical Sciences

October - November - December Issue 25 Autumn Winter Season Year: 2017

JEL CODE: A220-M490 ID:354 K:129

ISSN Print: 2146-8508 Online 2147-1711

(ISO 18001-OH-0090-13001706 / ISO 14001-EM-0090-13001706 / ISO 9001-QM-0090-13001706 / ISO 10002-CM-0090-13001706) (TRADEMARK)

(2015/04315- 2015-GE-18972)

neği), Akademik Bakış Dergisi, Sayı: 56: 220-240

\section{DALKIRAN, O., ALTINTAŞ, A., GÜNDÜZ,} N., SUNAY, H., AKGÜL, M., (2004). Ankara ili devlet ve özel ilk ve orta öğretim okullarındaki beden eğitimi öğretmenlerinin ders dışı etkinliklerinde kapa11 spor alanlarının etkin kullanımı üzerine görüşleri, O. ICHPER-SD Avrupa Kongresi ve 8 . SBD uluslar arası spor bilimleri kongresi kemer Antalya (CD-182_0394) ss. 2-4-14

\section{DEVLET PLANLAMA TEŞKILATI-DPT.} (1983). 5. Beş yıllık kalkınma planı spor özel ihtisas komisyonu raporu, Ankara

DINÇER, M.H., (1999). Koç Rehberi, Voleybol Antrenörleri Derneği, İstanbul.

ERDEMLI, A., (1991). Türk-Alman Kültür Diyalogunda Spor Ahlaki ve Spor Felsefesine Yeni Yaklaşımlar, Meya Matbaacıllk ve Yayımcılık, İstanbul

ESEN, S.A., (2010). “ilköğretim okullarında okuyan ve voleybol sporcusu olmay1 seçen öğrencilerin bu seçimlerindeki nedenler ve okul, aile, toplum faktörlerinin etkisi”, Marmara University Institute of Educational Sciences Department of Physical Education and Sports, Sports Education. Master's thesis., ss. 35, 53,54
FIŞEK, K., (1998). Dünya 'da ve Türkiye 'de devlet politikası ve toplumsal yapıyla ilişkileri açısından spor yönetimi, Bağırgan Yayım Evi, Ankara

FRÖHNER, B., (1999). Voleybol oyun kuramı ve alıştırmaları, Translation. Ali Cengiz, Bağırgan Yayınevi, Ankara

GÖKTAŞ, Z., (1994). Farklı Sosyo Ekonomik Yapıdaki Ortaöğretim Kurumlarında Okuyan Öğrencilerin Spora Katılımına Etki Eden Faktörler, Master's Thesis, Gazi University Institute of Health Sciences, Ankara, s.35

GÜVEN, $\ddot{O} ., \ddot{O} N C \ddot{U}, E$. , (2006). Beden eğitimi ve spora katılımda aile faktörü, Aile ve toplum eğitim, kültür ve araştırma dergisi, 3 (10): 81-90

IKIZZLER, H.C., TEKIN, A., (2008). Sporda fanatizme neden olan güdüler ve cinsiyet, Türkiye Kick Boks Federasyonu Spor Bilimleri Dergisi, 1 (1): 29

INAL, A.N., (2003). Beden eğitimi ve spor bilimi, Nobel Yayın Dağııım, Ankara

KANAT, M., SAVUCU, Y., SEZER, Y.S.,

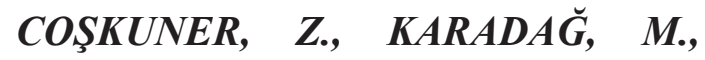
(2013). Analysis of basic value levels of sport high school and general high school students according to receiving physical education and sports courses. Journal of Educational Research, 4(6): 461 


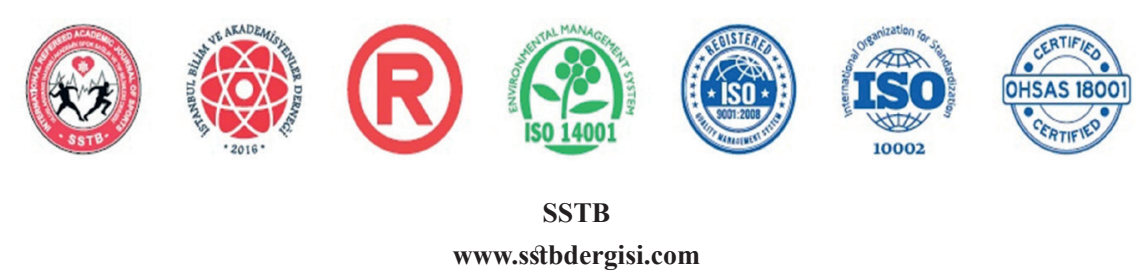

International Refereed Academic Journal of Sports, Health and Medical Sciences

October - November - December Issue 25 Autumn Winter Season Year: 2017

JEL CODE: A220-M490 ID:354 K:129

ISSN Print: 2146-8508 Online 2147-1711

(ISO 18001-OH-0090-13001706 / ISO 14001-EM-0090-13001706 / ISO 9001-QM-0090-13001706 / ISO 10002-CM-0090-13001706)

(TRADEMARK)

(2015/04315- 2015-GE-18972)

KARASÜLEYMANOĞLU, A., (1995). Yeni boyutlariyla spor, Ozan Dağıtım, Ankara

KILCIGIL, E., (1998). Sosyal çevre- spor ilişkileri, Bağırgan Yayınevi, Ankara, $1-169$

KIRIMOĞLU, H., ÇOKLUK, G., YILDIRIM, Y., (2010). Analysis of regional primary boarding school 6th, 7th and 8th Grade Students' Loneliness and Infelicity Levels According to Doing Sport Situation (Hatay Province Sample). Sportmetre Physical Education and Sport Sciences Magazine, VIII (3) 101-108

KONGAR, E., (1993). Kültür Üzerine, Remzi Kitabevi, Ankara, ss.1-207

LARSON, C.A., (1970). Curriculum foundation and standarts for physical education, Englewood Cliffs, New Jersey

MCPHERSON, B.D., CURTIS, J.E., LOY, J.W., (1986). The social significance of sport, Human Kinetics Publisher, Champaign

MENGÜTAY, S., (2006). Çocuklarda hareket gelişimi ve spor, Morpa Kültür Yayınları, İstanbul: 1-144

ÖZBAYRAKTAR, F., KURT, T., YÜCEL, E., KIVANÇ, C., HAN, A., KILIÇ, M.,
(2008). Sporda Organizasyon. 1st Edition, Kelebek Matbaacılık, İstanbul

ÖZMEN, Ö., (1999). Çağdaş sporda eğitim üçgeni, Bağırgan Yayım Evi, Ankara, $1-208$

ÖZTÜRK, F., (1998). Toplumsal boyutlariyla spor, Bağırgan Yayımevi, Ankara, s.61

SUNAY, H., (2010). Sporda organizasyon, 1st Edition, Gazi Kitabevi, Ankara, 1-162

TAŞMEKTEPLIGIL, Y., (1995). Sporun yaygınlaştırılmasında semt sahalarının etkileri, PhD Thesis, Marmara University Institute of Social Sciences

VARIŞ, F., (1994). Eğitimde program geliştirme, Alkım kitapçılık yayıncılık, Ankara

YETIM, A., (2005). Sosyoloji ve Spor, Morpa Kültür Yayınları, İstanbul

YILDIZ, Y., (2015). Spor yapan ve spor yapmayan üniversite öğrencilerinin sosyalleşme ve mutluluk düzeylerinin incelenmesi. Master's Thesis. Muğla Sitk1 Koçman University / Institute of Health Sciences / Department of Physical Education and Sports. Muğla, s. 79 